\title{
教室10年間の舌,口腔底癌症例の統計的観察
}

\author{
久保正治・山本正 宏* \\ 西 田正孝**.頭司研 作***

\section{Statistical Observations of Cancer of Tongue and Floor of the Mouth over a 10 Year Period}

\author{
Masaji Kubo, Masahiro Yamamoto \\ (Minami Osaka Hosp.) \\ Masataka Nishida and Kensaku Zushi \\ (Osaka Kita City Hosp.) (Osaka City Univ.)
}

We treated a total of 70 cases of cancer of the tongue and floor of the mouth over the last 10 years. According to $T$ classification, 16 cases fell under $T_{1}, 37$ cases or the largest number of the patients under $\mathrm{T}_{2}$, and 7 cases under $\mathrm{T}_{3}$. Swelling of the cervical lymphatic glands was seen in 40 cases.

The principal method of treatment was surgury, which was carried out in 46 cases. The combination of anti-cancer drugs, radiation and surgery was applied 28 cases and good cure rates were obtained. Of all cases, 30.4\% survived for 2 years, $27.5 \%$ for 3 years, $19.4 \%$ for 5 years and $28.6 \%$ for 7 years.

は じめに

頭頸部領域の悪性腫瘍の中でも舌， 口腔底癌の治療成績は喉頭，上顎に比べ低い。しかし，近年 は，手術法，放射線治療装置，並びに制癌剂の進歩により根治も不可能でない症例む少なくなく， 加えて近年の癌免疫療法による廷命効果も今後の課題として，その臨床適用が期待されているのが 現状である。

舌，口腔底癌は自覚症状並びに 他覚的所見が早期に現われ易い部位であり，治療も容易な身体表 在部位であるにかかわらず予後の悪い疾患であるととは領域リンパ節の転移の問題をぬきにしては 考えるととはできないであろう。即ち頸部リンパ節転移の治療の成否が予後を左右すると屯言える。

今回, 昭和 41 年より昭和 50 年迄の 10 年間に治療した舌, 口腔底癌の新鮮例 70 例について，各治療 法並びに遠隔成績を追跡検討する機会を得たのでここに御報告する。

\section{I 対象}

舌癌患者新鮮例 70 例が 昭和 41 年より昭和 50 年 末迄の 10 年間に治療され，男女別では，男子46

\footnotetext{
*総合病院南大阪病院耳鼻咽喉科

**大阪市立北市民病院耳鼻咽喉科

****大阪市立大学医学部耳鼻咽喉科学教室
} 
例，女子 24 例である。年令別では，男女共に60 才代が最屯多く，ついで40才代，50才代の順之 なっている。組織学的には 1 例の腺癌を除い て，すべて扁平上皮癌であった（表 1 ）。

表 1 年令及び性別

\begin{tabular}{c|r|r|r|r|r|r|r}
\hline \hline 年令 & $30 \sim$ & $40 \sim$ & $50 \sim$ & $60 \sim$ & $70 \sim$ & $80 \sim$ & 計 \\
\hline 男 & 2 & 11 & 11 & 15 & 7 & 0 & 46 \\
女 & 4 & 7 & 1 & 8 & 2 & 2 & 24 \\
\hline 計 & 6 & 18 & 12 & 23 & 9 & 2 & 70
\end{tabular}

70 例の主病変部位は，舌縁54例，口腔底11例， 舌根 5 例である。舌縁部が54例 (77\%) と最も 多かった（表 2 )。

表 2 舌主病変部位

\begin{tabular}{lll|r}
\hline \hline 舌 & & 縁 & 54 例 \\
口 & 腔 & 底 & 11 例 \\
舌 & & 根 & 5 例
\end{tabular}

\section{II 治 療 法}

過去10年間の治療法の内訳をみると，表 4 亿 示すように制癌剂，放射線並びに手術の三者併 用療法を行なった症例が最も多く28例を占め, 次いで手術的治療法を行なわない制癌剂之放射 線治療併用症例が18例あり，続いて放射線之手 術の15例の順となっている。

表 4 治 療 法

\begin{tabular}{|c|c|}
\hline 制癌剂＋放射線＋手術 & 28例 \\
\hline 制癌剂＋放射線 & 18例 \\
\hline 放射線＋手術 & 15例 \\
\hline 放射線 & 6例 \\
\hline 手術 & 2例 \\
\hline 制癌剂＋手術 & 1例 \\
\hline 計 & 70 例 \\
\hline
\end{tabular}

これらの治療法のうち，手術を施行した46例 の夫々の手術法を検討すると, 表 5 のでとくで， 舌の部分又は半側切除術之頸部郭清術を施行し た症例が26例と最も多く，次いで舌の部分又は
表 3 治療症例之 $\mathrm{TN}$ 分類

\begin{tabular}{c|r|r|r|r|r}
\hline & $\mathrm{N}_{U}$ & $\mathrm{~N}_{1}$ & $\mathrm{~N}_{2}$ & $\mathrm{~N}_{3}$ & \\
\hline $\mathrm{T}_{1}$ & 12 & 2 & 0 & 2 & 16 例 \\
$\mathrm{T}_{2}$ & $I 5$ & 11 & 3 & 8 & 37 例 \\
$\mathrm{T}_{3}$ & 3 & 2 & 4 & 8 & 17 例 \\
\hline & 30 & 15 & 7 & 18 & 70 例 \\
\hline & 30 & & 40 & &
\end{tabular}

新 $\mathrm{TN}$ 分類による病巣の拡がりは，表 3 亿示 すどとく $\mathrm{T}_{2}$ が最む多く37例で， $\mathrm{T}_{1}$ が16例， $\mathrm{T}_{3}$ が17例である。領域リンパ節の触知できた症 例は 40 例で，過半数が病変の進行した症例であ ったととが判る。頸部りンパ節腫張を認めた 40 例中 $\mathrm{N}_{1}$ 15例， $\mathrm{N}_{2} 7$ 例, $\mathrm{N}_{3}$ 18例で，両側頸部 に転移を認めた $\mathrm{N}_{2}$ 症例は全症例中の 7 例 (10 \%)であった。

表 5 手 術方 法

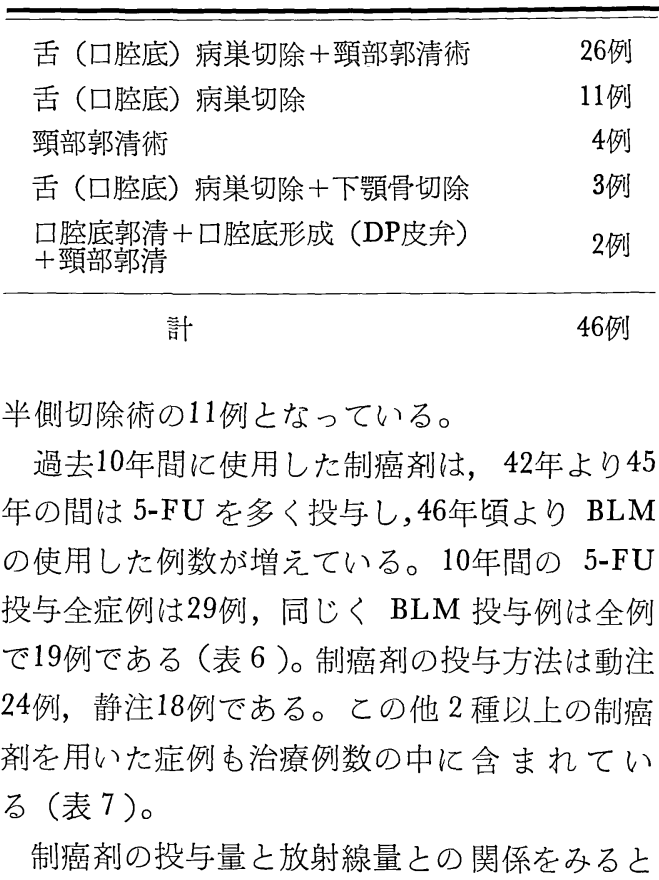


表 6 年度別制 癌 剂 使用症例数

\begin{tabular}{|c|c|c|c|c|c|c|c|c|c|c|c|}
\hline & 41年 & 42年 & 43年 & 44年 & 45年 & 46年. & 47年. & 48年 & 49年 & 50年 & 計 \\
\hline $5 \mathrm{FU}$ & 0 & 2 & 3 & 4 & 5 & 0 & 2 & 3 & 5 & 5 & 29 \\
\hline BLM & & & & 1 & 1 & 4 & 6 & 3 & 3 & 1 & 19 \\
\hline フトラフール & & & & & & & & & & 3 & 3 \\
\hline エスキノン & & & & & & & & & & 2 & 2 \\
\hline 計 & & 2 & 3 & 5 & 6 & 4 & 8 & 6 & 8 & 11 & 53例 \\
\hline
\end{tabular}

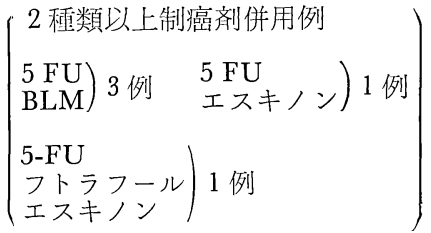

表 7 制癌剂投与例数之投与方法

\begin{tabular}{c|r|r|r}
\hline \hline & 動 注 & 静 注 & 計 \\
\hline $5 \mathrm{FU}$ & 19 & 5 & 24 \\
BLM & 5 & 11 & 16 \\
フトラフール & 0 & 2 & 2 \\
\hline & 24 & 18 & 42 例
\end{tabular}

$\left(\begin{array}{c}2 \text { 種類以上併用例 } 5 \text { 例 } \\ 5 \mathrm{FU}+\mathrm{BLM} \text { 動注 } 1 \\ 5 \mathrm{FU}+\mathrm{BLM} \text { 静注 } 1 \\ 5 \mathrm{FU} \text { 動注 }+\mathrm{BLM} \text { 静注 } 1 \\ 5 \mathrm{FU} \text { 動注 }+ \text { エスキノン静注 } 1 \\ 5 \mathrm{FU} \text { 動注 }+ \text { フトラフール } \text { エネノン 静注 } 1\end{array}\right)$

表 8 各制癌剂投与量と放射線量

\begin{tabular}{|c|c|c|c|}
\hline & & $\begin{array}{l}3000 \mathrm{R} \\
\text { 以上 }\end{array}$ & $\begin{array}{l}3000 \mathrm{R} \\
\text { 以 下 }\end{array}$ \\
\hline \multirow{2}{*}{$5 \mathrm{FU}$} & $2500 \mathrm{mg}$ 以上 & 17例 & 1例 \\
\hline & $2250 \mathrm{mg}$ 以下 & 8 & \\
\hline \multirow{2}{*}{ BLM } & $150 \mathrm{mg}$ 以上 & 9 & \\
\hline & $135 \mathrm{mg}$ 以下 & 9 & \\
\hline \multirow{2}{*}{ フトラフール } & $4000 \mathrm{mg}$ 以上 & 2 & \\
\hline & $4000 \mathrm{mg}$ 以下 & & \\
\hline エスキノン & & & 1 \\
\hline
\end{tabular}

5-FU 10回以上投与例が18例で，BLM 10 回以 上投与例は 9 例で $5-\mathrm{FU}$ 投与例の半数である。 放射線量は，ほ之んどが 4,000R 以上の線量で 照射在行なっている（表 8 ）。

\section{III 治 療 成 績}

70 例の粗生存率は表 9 に示すごとく，3 年生 存率 $27.5 \%, 5$ 年生存率 $19.4 \%$ であった。

てれを $\mathrm{TN}$ 分類別に粗生存率をみると, $\mathrm{T}_{1}$ 表 9 治療症例の粗生存率

$\begin{array}{ll}2 \text { 年生存率 } & 30.4 \%(17 / 56) \\ 3 \text { 年生存率 } & 27.5 \%(14 / 51) \\ 5 \text { 年生存率 } & 19.4 \%(7 / 36) \\ 7 \text { 年生存率 } & 28.6 \%(6 / 21)\end{array}$

表 $10 \mathrm{~T}$ 分類之粗生存率

\begin{tabular}{|c|c|c|c|c|}
\hline & 2 年生存率 & 3 年生存率 & 5 年生存率 & 7 年生存率 \\
\hline $\mathrm{T}_{1}$ & $\begin{array}{l}64.39 \% \\
(9 / 14)\end{array}$ & $\begin{array}{l}66.7 \% \\
(8 / 12)\end{array}$ & $\begin{array}{l}37.9 \% \\
(3 / 8)\end{array}$ & $\begin{array}{ll}75, \% \\
(3 ; & 4)\end{array}$ \\
\hline $\mathrm{T}$, & $\begin{array}{l}23.3 \% \\
(7 / 30)\end{array}$ & $\begin{array}{l}24.4 \% \\
(7 / 29)\end{array}$ & $\begin{array}{l}15 \% \\
(3 / 20)\end{array}$ & $\begin{array}{l}20 \% \\
(2 / 10)\end{array}$ \\
\hline $\mathrm{T}$. & $\begin{array}{r}8.3 \% \\
(1 / 12)\end{array}$ & $\begin{array}{l}10 \% \\
(1 / 10)\end{array}$ & $\begin{array}{l}12.5 \% \\
(1 / 8)\end{array}$ & $\begin{array}{l}14.4 \% \\
(1 / 7)\end{array}$ \\
\hline
\end{tabular}


症例 3 年生存率 $66.7 \%, 5$ 年生存率 $37.5 \%$ で, $\mathrm{T}_{2}$ 症例 3 年生存率 $24.4 \%, 5$ 年生存率 $15 \%$ で,

表11 治療法別にみた粗生存率

\begin{tabular}{|c|c|c|}
\hline & 3 年 & 5 年 \\
\hline 術 & $50 \% \quad(1 / 2)$ & $50 \%(1 / 2)$ \\
\hline 放 + 手術 & $15.4 \% \quad(2 / 13)$ & $16.7 \% \quad(2 / 12)$ \\
\hline 制 + 手術 & $100 \% \quad(1 / 1)$ & $100 \%(1 / 1)$ \\
\hline 制 + 放 & $16.7 \% \quad(2 / 12)$ & $14.3 \% \quad(1 / 7)$ \\
\hline 放 放 線 & $25 \%(1 / 4)$ & $0 \% \quad(0 / 2)$ \\
\hline 制＋放＋手 & $47.1 \% \quad(8 / 17)$ & $25 \% \quad(3 / 12)$ \\
\hline
\end{tabular}

表 12 制癌剂別及びその投与量と粗生存率

\begin{tabular}{|c|c|c|c|c|}
\hline & & 2 年 & 3 年 & 5 年 \\
\hline \multirow{2}{*}{$5-\mathrm{FU}$} & $\begin{array}{l}2500 \mathrm{mg} \\
\text { 以 上 }\end{array}$ & $\begin{array}{c}10 \% \\
1 / 10\end{array}$ & $\begin{array}{c}10 \% \\
1 / 10\end{array}$ & \multirow{2}{*}{$\begin{array}{c}11.1 \% \\
1 / 9 \\
20 \% \\
1 / 5\end{array}$} \\
\hline & $\underset{\text { 以 }}{2250 \mathrm{mg}}$. & $\begin{array}{c}25 \% \\
2 / 8\end{array}$ & $\begin{array}{c}28.6 \% \\
2 / 7\end{array}$ & \\
\hline \multirow{2}{*}{ B L M } & $150 \mathrm{mg}$ & $\begin{array}{c}33.3 \% \\
3 / 9\end{array}$ & $\begin{array}{c}37.5 \% \\
3 / 8\end{array}$ & $\begin{array}{c}33.3 \% \\
1 / 3\end{array}$ \\
\hline & 以 $150 \mathrm{mg}$ & $\begin{array}{c}40 \% \\
2 / 5\end{array}$ & $\begin{array}{c}40 \% \\
2 / 5\end{array}$ & $\begin{array}{c}33.3 \% \\
1 / 3\end{array}$ \\
\hline \multicolumn{2}{|c|}{$5-F U+B L M$} & $\begin{array}{c}\text { I00 } \% \\
3 / 3\end{array}$ & $\begin{array}{c}100 \% \\
2 / 2\end{array}$ & $0 \%$ \\
\hline
\end{tabular}

表13 制癌剂別及び投与法からみた粗生存率

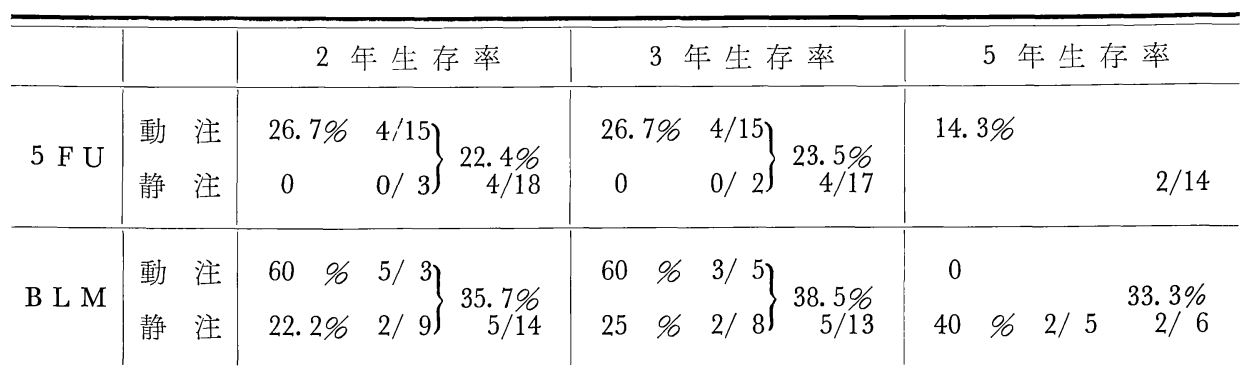

$\mathrm{T}_{3}$ 症例では 3 年生存率 $10 \%, 5$ 年生存率 $12.5 \%$ と進度が進めば，生存率は顕著に低下してい る(表10)。

次いで，治療法別に粗生存率をみると，表11 のごとくで，治療例数の最屯多い制癌剂・放射 線及び手術の三者併用療法施行例では 3 年生存 率 $47.1 \% ， 5$ 年生存率 $25 \%$ となり他の治療法之 比較し予後は良い。手術を施行しなかった制癌 剂之放射線治療の生存率は 3 年生存率 $16.7 \%$, 5 年生存率 $14.3 \%$ と成績は低い。

\section{IV 考}

舌癌の男女比は $1.9 ： 1$ であり從来の報告と

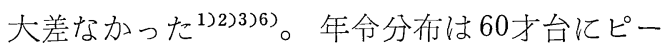
クを示しており，乙れあ従来の報告と同様であ った ${ }^{122) 3(6)}$ 。発生部位は, 従来の報告通り舌縁部 が好発部位とされており，私達の検討でも54例

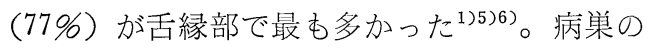

制癌剂別投与量と粗生存率をみると，表12の ごとくで，5-FU と BLM を比較するると，投 与量の多少にかかわらず BLM の方が $150 \mathrm{mg}$ 以上投与例 3 年生存率 $37.5 \%, 150 \mathrm{mg}$ 以下投与 例 3 年生存率 $40 \%$ 之成績は良い。又, 制癌剂の 投与方法別に粗生存率をみると，表12のごとく で，5-FU， BLM 共に動注の方がすぐれてい る。特に BLM の動注例で 3 年生存率 $60 \%$ と良 好である。

\section{按}

拡りを新 $\mathrm{TN}$ 分類によったが ${ }^{779)} ， \mathrm{~T}_{2}$ 症例が 37例（約 $50 \%$ ）と半数を占めた。頸部リンパ節 腫張を示した症例は70例中40例（57\%） と約半 数以上であり，特に $\mathrm{N}_{3}$ 症例は18例ありリンパ 節可動性ないものが多数にみられた ${ }^{4) 576) 8 。}$

治療法については, 制癌剤, 放射線並びに手 
術の組み合せが最む多く，その他，放射線と手 術, 制癌剂之手術, あるいは手術単独之組み合 せの中に手術を含めた治療法が最も多く 40 例と なっている。

制癌剂は .5-FU，BLM 共に10回の投与を目 標とし治療したが, BLM の場合 9 回未満症例 が BLM 投与例の半数を占め予期した治療量を 投与できなかった事が判る。投与法は動注及び 点滴静注を行なった。全動注例は24例, 静注例 は18例で，動注施行例が多く特に 5-FU には 動注例が多く, BLM では静注例が多かった。

放射線治療は $15 \mathrm{MeV}$ ベータトロンX線又は 電子線と，1例にデルモパンの外照射を用い, 1 例にベータトロン電子線を用いて Tubus に よる腔内照射を行った。放射線治療症例のうち 1 例を除き，すべては $3,000 \mathrm{R}$ 以上照射してい る。我々の症例の中に, 放射線之制癌剂之の治 療で, 7 年健在の $\mathrm{T}_{3} \mathrm{~N}_{3}$ 症例があり, 非観血 的な治療で適応が正しければ根治可能な場合の ある事を強調したい。

原発巣及び頸部転移の状態による治療法と予 後をみると, $\mathrm{T}_{1} \mathrm{~N}_{0}$ 症例は 12 例あり, 放射線 と手術が 4 例で 3 年生存 2 例, 制癌剂之放射線 及び手術が 6 例で 3 年生存 4 例, 制癌剂之放射 線が 2 例で 3 年生存 2 例である。 $\mathrm{T}_{2} \mathrm{~N}_{0}$ 症例は 15 例で, 制癌剂と放射線及び手術が 6 例で 3 年 生存 5 例之成績良く, 制癌剂之放射線治療は 5 例で 3 年生存 1 例となっている。その他, 手術 単独 1 例と制癌剂之手術 1 例は追跡不能で, 放 射線之手術 1 例及び放射線単独の 1 例は予後不 良であった。 $\mathrm{T}_{2} \mathrm{~N}_{0}$ 症例15例のうち手術を施行 した症例は 9 例で, 病巣切除と頸部郭清術が 4 例, 病巣切除之保存的頸部郭清術が 2 例, 病巣 切除のみが 3 例である。 $\mathrm{T}_{2} \mathrm{~N}_{0}$ 症例に対する治 療法は舌病巣の治癒を目的とし, 放射線治療と 制癌剂の投与を施行し, 主として舌半側切除術 を行なっている。術前治療中に患側頸部に転移 を認めた例は 4 例あり，頸部郭清術を行なって いる。臨床的に頸部転移の認められない場合に 屯保存的頸部郭清術を施行した方が治療成績は
良(と考える ${ }^{455) 8) 。 ~}$

$\mathrm{T}_{3} \mathrm{~N}_{0}$ 症例に対する治療症例は成績が悪い。 舌病巣の大きいものは早期に転移を起し易く, 特に両側に転移を起し易い ${ }^{4)} 。 \mathrm{~T}_{3} \mathrm{~N}_{0}$ 症例は 3 例で，うち 1 例は動注と放射線治療中下顎部に 転移を認め頸部郭清術と舌半側切除術を施行し たが，5ケ月後頸部に再発し死亡している。

以上頸部転移のない症例を検討したが，初治 療でリンパ節を触知できなくても充分な注意が 必要と考えられる。

頸部転移の認められる症例に抢いては，舌病 巣の治癒を目的とした動注と放射線治療を行な い, 照射終了後可及的早期に頸部郭清術を施行 すべきである。特に， $\mathrm{T}_{2} \mathrm{~T}_{3}$ に抢いては，舌病 巣と頸部転移巣を含めた広範囲な en-bloc の手 術が必要となる。私達の教室における頸部転移 の認められた $\mathrm{T}_{2}$ 症例は22例あり, うち手術を 施行しえた症例は 9 例である。頸部りンパ節が 固定性であったり，両側頸部にリンパ節が腫張 しているむののなかで，手術の適応にならない 症例は主として放射線治療及び全身的な制癌剂 の静脈内投与を行なった。手術を施行しえた 9 例は舌半側切除と患側頸部郭清術を施行した が， 3 年生存例は 2 例と成績不良であった。 1 例は $\mathrm{T}_{2} \mathrm{~N}_{2}$ の口腔底癌で, 舌, 下顎及び両頸部 に計 $8100 \mathrm{R}$ 照射し, 併行して 5-FU $250 \mathrm{mg}$ 20 回静脈内投与した。舌病巣は非常に縮少した が残存しており，患側頸部郭清術を行ない舌病 巣之共に en-bloc に摘出し, D-P 皮弁による 口腔底形成術を行ない 2 年経過している。 $\mathrm{T}_{2}$ 症 例の成績は不良で, 舌病巣の拡がりが大きい程 当然転移の進展も早いと考えられる。 $\mathrm{T}_{2}$ 症例で は，舌病巣と頸転移巣を含めた治療方針が必要 である。制癌剤による舌病巣への動注法も充分

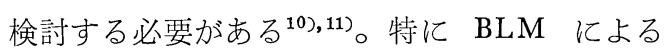
動注の成績が良く，放射線との併用により舌病 巣の治癒をはかるべきである。しかし，制癌剤 による副作用, 特に BLM による発熱, 肺線維 症には充分な注意が必要であり，放射線による 粘膜炎，皮膚炎にも注意し，局所，全身を観察 
しつつ術前の治療効果をあげる必要がある。

$\mathrm{T}_{3}$ 症例は17例で頸部転移の認められた症例 は14例之多い。生存例は 1 例之成績は全く不良 である。手術を施行できた症例は 9 例である が，局所の再発を認め予後不良であった。

特に口腔底，下顎骨の処理が問題である。 $\mathrm{T}_{3}$ $\mathrm{N}_{3}$ 症例で, 5-FU $250 \mathrm{mg}$ 17回動注, 併行して 放射線 4,000 R 照射後, 口腔底郭清術, 患側頸 部郭清術を en-bloc に施行し, D-P 皮弁による 口腔底形成術を行ない，局所再発なく 1 年生存 している。舆下障害は認められず，軽度の構音
障害が認められる。高度進展例に対しては, 術 前処置として, 舌病巣の縮少をはかり, en-bloc に頸部病巣と共に摘出し再建をはかるべきと考 える。

最後に私達の全治療症例の粗生存率を示す 之, 2 年生存率 $30.4 \%, 3$ 年生存率 $27.5 \%, 5$ 年生存率 $19.4 \%, 7$ 年生存率 $28.6 \%$ となり, 他 施設に比し必ずしも良好ではないが，症例によ っては適切な治療を行なうことによって長期生 存する場合あ少なくないことを知るととができ た。

\section{ま と め}

1. 昭和 41 年より昭和 50 年迄の 10 年間の舌, 口腔底癌の新鮮例について治療法, 予後を統計的に 検討した。

2. 70 例のうち男性 46 例，女性 24 例で， 60 才台が 23 例で最屯多く，30才台の若年者癌が 6 名，80 才台の高令者癌が 2 名で両群とも女性の患者が多かった。

3. 主病巣は舌縁が最も多く54例, $\mathrm{T}$ 分類は， $\mathrm{T}_{1}$ が16例， $\mathrm{T}_{2}$ が最も多く 37 例， $\mathrm{T}_{3}$ が 17 例で, 頸 部リンパ節触知できたものは40例で，約半数以上に認められた。

4. 手術的治療を行なった症例は46例で, 治療の主体を占める。中でも舌病巣切除術, 口腔底郭 清術と頸部郭清術の術式が最む多く26例で, 最近では口腔底癌症例に, 口腔底郭清術と口腔底形成 術（D-P 皮弁）及び頸部郭清術施行例 2 例含まれており，治療経過も良い。

5. 治療法の組み合せは，制癌剤，放射線及び手術の三者併用療法が 28 例で，制癌剤の種類は 5-FU，BLM が主で，5-FU は45年迄多く用いられ，48年頃より再び多用され，一方，BLM は46年 47 年に使用例数が多い。投与法は動注が24例，静注は18例で，5-FU の方が動注使用例が多かった。 投与量は 5-Fu 10回（2,500 mg）以上のあのが多いが，BLM の場合，10回（150 mg）以上投与し た症例之 9 回未満投与例は同数であった。

6. 制癌剤の投与法からみた生存率では，5-FU，BLM 共に動注の方が優れていた。ただし，薬 剤別では BLM の方が遠隔成績は良い。5-FU，BLM 共に投与量による生存率の差異は特に有為な 差はみられなかった。

7. 治療法別では，三者併用症例の生存率が良く，統計的に有意義である。

8. $\mathrm{T}$ 分類別では, $\mathrm{T}_{1}$ の生存率が最む良く, 5 年生存率では $37.5 \%, \mathrm{~T}_{2} 15 \%, \mathrm{~T}_{3} 12.5 \%$ あっ た。

9. 全治療症例の粗生存率は, 2 年生存率 $30.4 \%, 3$ 年生存率 $27.5 \%, 5$ 年生存率 $19.4 \%, 7$ 年生 存率 $28.6 \%$ あっむた。

本論文の要旨は昭和51年10月, 第14回日本癌治療学会総会に扑いて発表した。 
文

1）山本馨，他：私達の教室の過去10年間に抢ける 舌癌の統計的観察. 耳鼻臨床 61: 1095-1097, 1968.

2）岩井一, 他：舌癌の手術的治療に対する考察. 耳鼻臨床 $60 ：$ 819-824, 1967.

3）河辺義孝: 舌癌に対スる治療法の検討. 耳鼻臨 床 62:245-254, 1969 .

4) 奥田稔, 他：舌癌の転移について, 耳喉 36 : 907-914, 1964.

5）竹田千里, 他：進展別にみた舌癌の治療方針の 検討, 日癌治 $2: 261-270,1967$.

6）斎藤等，他：わが教室 16 年間の舌悪性腫瘍の統 計的観察, 耳喉 45:33-40, 1973.

7) 斎藤等, 他 : 舌癌に対する新旧, 両 $\mathrm{T} \mathrm{N}$ 分類の 評価, 耳鼻臨床 69 : 1149-1153, 1976.
献

8）市川昭則, 他：教室における舌癌の遠隔成績. 耳鼻 22: 713-720, 1976.

9) UICG: TNM classification of malignant tumors. UICG, Geneva, 1974.

10）高橋広臣：頭頸部領域悪性腫瘍に対する制癌剂 動脈内投与法の臨床的研笲. 日耳鼻 $70: 566-$ 606, 1967.

11）犬山征夫：頭頸部悪性腫瘍に対する制癌剂の動 脈内注入法に関する臨床的研究. 日耳鼻 70 : 612-640, 1967.

原稿到着：昭和52年 10 月 22 日 別刷請求先 : 久保正治 厂559 大阪市住之江区東加賀屋 1 丁目 18番 18 号

総合病院南大阪病院耳鼻咽唉科 